\title{
Comparative LaW in the Reasoning OF The European Court OF HumAn Rights
}

\section{INTRODUCTION}

The European Court of Human Rights has begun using comparative law in its judgments at an early stage. The Court regularly invokes the domestic law of the contracting parties, refers to international treaties and cites judgments from Canada, the United States, South Africa and other jurisdictions. The author submits that properly conducted comparative research can provide the European Court of Human Rights with objective information regarding particular legal matters and offer solutions in Europe and worldwide. This paper will explore the way in which the European Court of Human Rights conducts its comparative analysis. Comparative analysis often proves to be a precondition for the European Court of Human Rights, without which it will not rule on the presence or absence of European consensus in a particular area of law.

In the first part of this article, an examination of the purpose of comparative analysis in the Court's case law will be undertaken. It is submitted that, depending on the role comparative analysis plays in the particular case, its impact can be identified on different levels of the court's reasoning, namely as background information or persuasive argument. If the European Court of Human Rights simply quotes comparative data without further examination and does not come to a conclusion about the presence or absence of a European consensus, the comparative data serves an informative purpose. Comparative data is designed to inform the judges about possible solutions to the matter at issue. If the results of the comparative survey affect the reasoning of the Court directly, one can conclude that the purpose of this data is persuasive.

Part II focuses on the justification and role of comparative analysis in the European Court of Human Rights' jurisprudence. In general, commentators perceive comparative analysis quite positively. It has been argued, however, that judges of the 
Court can sometimes find themselves in the position of legislating for Europe, as the European Convention on Human Rights is a 'law-making treaty' ${ }^{1}$ but this 'lawmaking' cannot be conducted in vacuum and for that reason comparative analysis provides valuable guidance for judges.

Part III is concerned with possible challenges in comparative law. These challenges and pitfalls are mostly explored in the context of academic comparative analysis. Not all of them are directly applicable to the comparative research conducted by the European Court of Human Rights. The ultimate aim of Part III is to describe possible challenges and to determine the extent to which these pitfalls are applicable to the practice of the Court. Three of the most common problems are examined: cultural bias of comparative research, legal terms translation and law 'cherry picking'. The Court is in a better position than many academic institutions to engage in comparative research due to the fact that the research is conducted by lawyers from the states in question. Moreover, legal systems in Europe, while diverse, are not completely incompatible.

In Part IV, methodology of comparison is outlined. There is no consensus in legal scholarship regarding the stages through which every comparative analysis should go and the content of these stages. Moreover, comparative research in the European Court of Human Rights is different from that which is academic; therefore, the stages developed for academic research are not directly applicable to comparative law in the Court. This section focuses on two aspects of comparative law in the Court: collecting and assessing the data. In circumstances where the comparative analysis serves informative purposes, the Court does not assess it; assessment is understood here as a consequence of comparative analysis that can affect the final judgment directly. It is argued that neither established consensus nor lack of it automatically means that the Court will come to a certain conclusion in the case provided by this consensus. It establishes a rebuttable presumption that can be overcome by other means of interpretation. However, this does not diminish the value of comparative law because the reasons for rejection of the consensus argument must be highly persuasive.

\footnotetext{
${ }^{1}$ Loizidou v. Turkey (App no 15318/89) (1996) ECHR 70 (18 December 1996) 84.
} 


\section{Purposes of Comparative LaW}

Comparative law and comparative research were originally part of legal theory 'not immediately relevant to the daily life of the law'"2 they were considered to be nothing more than an amusing puzzle. ${ }^{3}$ However, in the modern globalised world which requires everyday interaction between legal systems, application of comparative law has become highly relevant in practice. It provides useful data for legislators on a domestic level, drafters of international treaties and it can also assist lawyers working for international organisations and quasi-judicial institutions in interpreting international treaties. Reitz distinguished certain sets of purposes for a comparative analysis:

Comparative study of law can be undertaken simply to inform the reader about foreign law, perhaps for the practical purpose of facilitating an international transaction or resolving a conflict of laws problem. It may be part of a campaign of law reform. It may be part of a comparative study of human culture or part of a critical project aimed at exposing the way law masks the exercise of power. It can even be used to spoof legal scholarship. ${ }^{4}$

The European Court of Human Rights often uses comparative analysis in its reasoning. Örücü argues that 'in developing the law, especially when the law is inadequate, or in expending the law, judges may look at foreign jurisdictions to achieve uniformity with civilised world ${ }^{5}$ While this idea is more applicable to the national judiciary, it is also useful in the case of the European Court of Human Rights.

\footnotetext{
2 T Koopmans, 'Comparative Law and the Courts' (1996) 45 International and Comparative Law Quarterly 545, 545.

3 WJ Kamba, 'Comparative Law: A Theoretical Framework' (1974) 23 The International and Comparative Law Quarterly 485, 489.

${ }^{4}$ JC Reitz, 'How to Do Comparative Law' (1996) 46 The American Journal of Comparative Law 617, 624.

${ }^{5}$ E Örücü, 'Whither Comparativism in Human Rights Cases?' in E Örücü (ed), Judicial Comparativism in Human Rights Cases (UKNCCL, London 2003), 237.
} 
The Court operates in conjunction with national legal orders and should have an indication about the way a particular legal matter is normally dealt with in Member States. Örücü continues:

As the ECHR frequently uses general and often inconclusively worded formulations that necessitate "fleshing out" through interpretation and, as many of the rights contain no substantive criteria, judges of the Strasbourg court themselves have to become active law-makers. Nevertheless this function is not carried out in a vacuum. Comparative reference to the growing corpus of human rights law in the international and supranational fields likewise represents a persuasive, if not binding source of international assistance. ${ }^{6}$

For that reason, comparative law is no longer simply an amusing puzzle; it serves a practical purpose and can affect the final judgment of the European Court of Human Rights. Michael O'Boyle, the Deputy Registrar of the Court, argues that if there is a 'crushing' majority of the Contracting Parties adopting a particular solution, it makes this solution very appealing to the judges. ${ }^{7}$

Traditionally, scholars have pointed out that comparative law might have practical application only in the case of a conflict of laws, for example, in international trade. $^{8}$ In the European Court of Human Rights, comparative law analysis serves two main purposes: to inform and to persuade. Judges ${ }^{9}$ of the Court mentioned these two purposes in interviews which the author of this paper conducted; these two purposes are also easily identifiable within the text of certain judgments. For instance, in Burden $v$. the United Kingdom, ${ }^{10}$ the legal matter in question was whether cohabiting sisters could be compared with married couples and same-sex partners in civil

\footnotetext{
${ }^{6}$ ibid 239.

${ }^{7}$ K Dzehtsiarou, Unpublished Interview with Michael O'Boyle (European Court of Human Rights, Strasbourg 2009).

${ }^{8}$ DJ Gerber, 'System Dynamics: Toward a Language of Comparative Law?' (1998) 46 The American Journal of Comparative Law 719, 720.

${ }_{9}^{9}$ K Dzehtsiarou, Unpublished interview with Judge Malinverni (European Court of Human Rights, Strasbourg 2009).

${ }^{10}$ Burden v. United Kingdom (App no 13378/05) [2008] 3 BTC.
} 
partnerships for the purposes of inheritance tax. A husband succeeding his wife or a wife succeeding her husband, as well as a partner succeeding another partner, is exempt from inheritance tax in the United Kingdom. The Court's judgment included Chapter 3 entitled 'Relevant comparative law and material'; it contained comparative analysis of the domestic legislation of some of the Contracting Parties regarding the matter at issue. The Court did not identify any commonly accepted standard in the area. $^{11}$

The European Court of Human Rights acknowledged that the legislation in respect of inheritance tax is diverse in Europe and confirmed that some Contracting Parties might allow tax exemption for siblings. Nevertheless, the Court stated that the matter in this case was more related to the legal difference between married couples and cohabiting siblings than taxation policy in the Member States:

Just as there can be no analogy between married and Civil Partnership Act couples, on one hand, and heterosexual or homosexual couples who choose to live together but not to become husband and wife or civil partners, on the other hand, the absence of such a legally binding agreement between the applicants renders their relationship of cohabitation, despite its long duration, fundamentally different to that of a married or civil partnership couple. This view is unaffected by the fact that...Member States have adopted a variety of different rules of succession as between survivors of a marriage, civil partnership and those in a close family relationship and have similarly adopted different policies as regards the grant of inheritance tax exemptions to the various categories of survivor; States, in principle, remaining free to devise different rules in the field of taxation policy. ${ }^{12}$

The fact that there is no consensus in Europe regarding the matter at issue did not play a decisive role in the Court's conclusion that there was no violation by the Contracting

\footnotetext{
${ }^{11}$ ibid 26.

12 ibid 65.
} 
Party. The Court stated that there is fundamental difference between cohabiting sisters and a married couple which cannot be rebutted by an agreement among the Contracting Parties; in any event, there is no such agreement. The European Court of Human Rights noted that the legislation of Contracting Parties might change but that this would not change the legal character of the matter. For that reason, the comparative data in this case served only an informative purpose and did not affect the final judgment directly.

Comparative data also served informative purpose in the case K.U. v. Finland. ${ }^{13}$ In this case, the European Court of Human Rights dealt with the issue of protection of privacy on the Internet, specifically where an unknown person disclosed personal information about the 12-year old applicant on a dating website. The service provider, however, refused to divulge the identity of the holder of the IP address in question, suggesting that it was bound by the confidentiality of telecommunications as defined by law. The applicant complained to the European Court of Human Rights that Finland failed to fulfil its obligations under Article 8 of the Convention. ${ }^{14}$ The Court cited comparative data in its judgment in very general terms:

A comparative review of national legislation of the member States of the Council of Europe shows that in most countries there is a specific obligation on the part of telecommunications service providers to submit computer data, including subscriber information, in response to a request by the investigating or judicial authorities, regardless of the nature of a crime. ${ }^{15}$

This information was not referred to in the ratio decidendi of the judgment. Despite the fact that the Court mentioned the margin of appreciation of the Contracting Party ${ }^{16}$ and 'converging standards' as limits for the margin of

\footnotetext{
${ }^{13}$ K.U. v. Finland (App no 2872/02) [2008] Unpublished.

${ }^{14} \mathrm{Right}$ to respect for private and family life.

${ }_{16}^{15}$ K.U. v. Finland (n 13) 32.

${ }^{16}$ ibid 43.
} 
appreciation, ${ }^{17}$ it was articulated in general terms and was not explicitly applied in the present case. The Court instead used the principle of effectiveness of rights as an interpretive tool in this case. ${ }^{18}$ While not being dispositive in this case, comparative analysis was used to support the findings of the Court which were made by other means of interpretation. Mahoney argues that ' $[\mathrm{t}]$ he comparative method in the ECHR system serves as an evidentiary accompaniment or supporting factor for other interpretative considerations that point to a given meaning.${ }^{19}$ However, it is not the only purpose which comparative analysis serves in the European Court of Human Rights' case law.

In a number of cases, the Court has used comparative data to determine the presence or absence of a European consensus or a common trend in respect to a particular legal issue. In Unal Tekeli v. Turkey, ${ }^{20}$ for instance, the European Court of Human Rights considered Turkish legislation, which forbade married women from retaining their maiden names, in light of the rules accepted by the majority of states. Comparative data can be found in this judgment in the chapter dedicated to international law. In this case, the Court cited the same wording regarding the margin of appreciation and its limits as in K.U. v. Finland but, unlike the latter case, the Court in Unal Tekeli conducted more probative assessment of the issue. It stated that:

[T] he Court notes the emergence of a consensus among the Contracting States of the Council of Europe in favour of choosing the spouses' family name on an equal footing. Of the member states of the Council of Europe Turkey is the only country which legally imposes - even where the couple prefers an alternative arrangement - the husband's name as the couple's surname and thus the automatic loss of the woman's own surname on her marriage. ${ }^{21}$

\footnotetext{
17 ibid 44.

${ }^{18}$ ibid 49.

${ }^{19}$ P Mahoney, 'The Comparative Method in Judgments of the European Court of Human Rights: Reference Back to National Law' in M.A. Guy Canivet, Duncan Fairgrieve (eds) Comparative Law Before the Courts (BIICL, London 2004) 146.

${ }^{20}$ Unal Tekeli v. Turkey (App no 48616/99) [2004] .

${ }^{21}$ ibid 61.
} 
Moreover, the Court cited common European practice as a counterargument to the Government's submission that the legal position in Turkish legislation was justified by the necessity of 'reflecting family unity through a joint family name' ${ }^{22}$ In contrast to the above mentioned Burden v. the United Kingdom and K.U. v Finland cases, the European Court of Human Rights explicitly articulated the place of comparative analysis in its reasoning: the Court analyzed the state of European legislation and concluded that a European consensus existed. Comparative analysis is an important precondition for the determination of the presence and absence of consensus. If the Court comes to this conclusion, comparative analysis can be said to be have persuasive value in the Court's reasoning.

\section{ROLE AND JUSTIFICATION OF COMPARATIVE RESEARCH}

As mentioned above, comparative law can enable the European Court of Human Rights to rule on the presence or absence of consensus on a particular matter, but the value of comparative law is not limited to this. Comparative law can serve as a source of information for judges in the search for an appropriate answer to a given question.

The legitimacy of recourse to comparative law is addressed by Mahoney as follows:

The mission of the Strasbourg Court often involves ruling on the compatibility of the laws and practices of a contracting State with the requirements of the ECHR. It might therefore be asked whether, in order to accomplish that mission of international judicial control, it is at all legitimate to rely on a comparative reference back to national legislation. $^{23}$

\footnotetext{
${ }^{22}$ ibid 68.

${ }^{23}$ Mahoney (n 19) 145.
} 
Mahoney answers this question positively and argued that the European Court of Human Rights often faces situations in which the legal solution does not clearly follow from the Convention and judges find themselves in the position of legislators. However, judicial law-making cannot be conducted in vacuum. He emphasised the subsidiary role of the Court to national legal systems and this, in his opinion, justifies references to the law of Contracting Parties. ${ }^{24}$ Örücü went even further and argued that '[c]omparativism is inherent in the ECHR system of protection'. ${ }^{25}$ According to Örücü, '[c]omparativism [is] much at the heart of human rights cases, if human rights are to be regarded as embodying principles that are universal rather that purely domestic or even European. ${ }^{26}$ Indeed, she goes on to note that '[i]t is true that most of the time reference to other jurisdictions gives broader legitimacy to judicial decisions in human rights cases'.27

While quite positive about comparative law in the jurisdiction of the European Court of Human Rights, commentators emphasise different aspects of its role. On the one hand, Delmas-Marty argues that comparative law is a tool that might restrict judicial arbitrariness and therefore legitimises a court's judgment. She maintains that judicial arbitrariness cannot be avoided by procedural rules alone; substantive rules, which comparative law can help to define, bring more confidence in judicial creativity in the European Court of Human Rights. ${ }^{28}$ Judges might take a more active position if this position is supported by generally adopted practices of the majority of Contracting Parties, while remaining reluctant to 'rewrite the Convention to help an individual. ${ }^{29}$

Barak contends that if the judge has comparative law to support him, he is more certain that he is standing on safe ground. The European Court of Human Rights does not seem willing to prohibit the use of comparative analysis in its reasoning; on the contrary, recent developments show a more scientific approach to comparative

\footnotetext{
${ }^{24}$ ibid 136-137.

${ }^{25}$ Örücü (n 5) 238.

${ }^{26}$ ibid 230.

${ }^{27}$ ibid 237.

${ }^{28}$ M Delmas-Marty, 'The Contribution of Comparative Law to a Pluralist Conception of International Criminal Law' (2003) 1 Journal of International Criminal Justice 13, 25.

${ }_{29}$ A Mowbray, 'The Creativity of the European Court of Human Rights' (2005) 5 Human Rights Law Review 57, 69-70.
} 
law. The Court now has a research department which is designed to undertake comparative analysis following the request of the Judge Rapporteur.

There are objective reasons why both national courts and international tribunals use comparative law in their reasoning. Koopmans argues that comparative legal analysis is used more widely by the courts as a result of new social problems which emerged and legislators who are not in a position to cope with these matters sufficiently. ${ }^{30}$ This is also relevant in the case of international tribunals like the European Court of Human Rights. Negotiations regarding new protocols are extremely lengthy and complicated. New protocols must be adopted by all forty seven Contracting Parties and the Court often cannot wait until formal agreement from the Contracting Parties has been secured.

Mahoney notes that one exaggerates when stating that the European Court of Human Rights uses 'comparative analysis. ${ }^{31}$ Indeed, comparative data, if cited by the Court, is often far from comprehensive. Some commentators argue that the Court uses the argument of European consensus without reference to any comparative research. In the well-known Tyrer case ${ }^{32}$ the Court did not cite any comparative data but came to the conclusion that there was European accord with respect to corporal punishment. However, since Tyrer, the European Court of Human Rights has developed from a body which sits in sessions and considers 4 to 5 cases a year to a permanent court which considers more than one thousand cases per annum. ${ }^{33}$ The workload of the Court has increased substantively and at the same time, the importance of its judgments has risen significantly. The quality of judgment is extremely important for the authority and legitimacy of the European Court of Human Rights. For this reason, the Court conducts comprehensive and reliable comparative research that can support its findings. After the Research Department was included in the Court's Registry, it appeared to be fully equipped to undertake such high quality research.

\footnotetext{
${ }^{30}$ Koopmans (n 2) 549.

${ }^{31}$ Mahoney (n 23) 149.

${ }^{32}$ Tyrer $v$. the United Kingdom (App no 5856/72) (1978) 2 EHRR1, [1978] ECHR 2.

${ }^{33}$ The Court delivered 2,395 judgments in 2009, see European Court of Human Rights Annual Report 2009 (Registry of the European Court of Human Rights Strasbourg, 2010), available at $<$ http://www.echr.coe.int/NR/rdonlyres/C25277F5-BCAE-4401-BC9B-

F58D015E4D54/0/Annual_Report_2009_Final.pdf> accessed 15 August 2010.
} 


\section{Challenges of Comparative Studies}

Regardless of whether comparative data serves an informative or persuasive purpose, it should be objective and adequate. There are a number of possible challenges that a tribunal involved in comparative analysis can face. These challenges will be examined to determine the extent to which they are relevant to the comparative research undertaken by the European Court of Human Rights.

\section{IV.I Bias and Cultural Determinacy of Comparative Analysis}

Many scholars have referred to a bias-based argument in their research of comparative law methods. ${ }^{34}$ The main thesis of this argument is based on the cultural and social determinacy of comparative research. Scholarship, it is contended, is predominantly 'western-dominated and western-biased. ${ }^{35}$ This threatens comparative research in the practical dimension of the European Court of Human Rights' jurisprudence, which must be as objective as possible. Bias in comparative research is not as significant a problem in Europe as it is on an international level due to the more diverse nature of laws worldwide. Democratic values should be respected by the Member States of the Council of Europe and accepted by virtue of entry to the Convention. This idea is reflected in the Convention's Preamble, which states that 'the governments of European countries...are like-minded and have a common heritage of political traditions, ideals, freedom and the rule of law'. However, it is widely accepted that Europe is still diverse, both legally and culturally. Some commentators, for instance, argue that 'individual freedom had and still has rather different meaning in Russia or China compared to the Western view, not just because of a communist ideology currently or formerly imposed by the rulers in those countries, but because of

\footnotetext{
${ }^{34}$ VG Curran, 'Cultural Immersion, Difference and Categories in U. S. Comparative Law' 'American Society of Comparative Law' (1998) 46 The American Journal of Comparative Law 43, 58; J Hill, 'Comparative Law, Law Reform and Legal Theory' (1989) 9 Oxford Journal of Legal Studies 101, 107.

${ }^{35}$ A Peters and H Schwenke, 'Comparative Law beyond Post-Modernism' (2000) 49 International and Comparative Law Quarterly 800, 821.
} 
a more basic, culturally embedded ideology which starts from a very different, collectivist world view. ${ }^{36}$

A number of the Contracting Parties to the Convention were communist states not more than 20 years ago. Comparativists quite frequently do not take cultural diversity of this kind into account. Cultural determinacy of adequate comparative research is highlighted by a number of scholars. According to their collective view, law is more than just a sum of legal provisions. ${ }^{37}$ Mahoney argues that 'national rules cannot simply be compared in isolation but have above all to be understood in their local context, in relation to the national legal system concerned and their operation in practice - should prevent its being given any such determinative effect. ${ }^{38}$ Moreover, certain extra-legal factors such as customs and legal practices should be taken into consideration. ${ }^{39}$ In some countries, the law as expressed in textbooks is quite different to the law under which people live. ${ }^{40}$ The same legal norm might have completely different effects in different legal systems precisely because legal practice is different. The European Court of Human Rights takes this notion into account. In Tanase and Chirtoaca v. Moldova, the Court explored Member States' legislation regarding dual citizenship. The Court stated '[i]n some of the countries which ban double nationality, in practice the provisions aimed at preventing multiple nationalities have remained a dead letter (for instance Estonia). ${ }^{41}$ Hoecke and Warrington argue that if the cultural parameters are not taken into account one might find much more similarities that there are in reality. ${ }^{42}$

For these reasons, a number of comparativists argue that norm-centred comparison does not provide adequate results. ${ }^{43}$ Stone argues that in order to complete an objective comparative survey '[w]e must study the history, the politics, the

\footnotetext{
${ }^{36}$ MV Hoecke and M Warrington, 'Legal Cultures, Legal paradigms and legal doctrine: towards a new model for comparative law' (1998) 47 International \& Comparative Law Quarterly 495, 511.

${ }^{37}$ C Valcke, 'Comparative Law as Comparative Jurisprudence: The Comparability of Legal Systems' (2004) 52 The American Journal of Comparative Law 713, 717.

${ }^{38}$ Mahoney (n 19) 146.

${ }^{39} \mathrm{P}$ de Cruz, Comparative Law in a Changing World (Cavendish Publishing Limited, London, Sydney 1999), 230.

${ }^{40}$ Reitz (n 4) 630; W Ewald, 'The Jurisprudential Approach to Comparative Law: A Field Guide to "Rats"' (1998) 46 The American Journal of Comparative Law, 701, 702.

${ }^{41}$ Tănase and Chirtoacă v. Moldova (App no 7/08) 2008 Unpublished, 49.

${ }^{42}$ Hoecke and Warrington (n 36) 511.

${ }^{43}$ Gerber (n 8) 721.
} 
economics, the cultural background in literature and the arts, the religion, beliefs and practices, the philosophies, if we are to reach sound conclusions as to what is and what is not common'. ${ }^{44}$ This idealistic approach was criticised by Cruz as impractical, because it is hardly possible to be a specialist in all these areas and it is not always necessary to consider such detail ${ }^{45}$.

The European Court of Human Rights might find itself in a more advantageous position than most involved in an academic comparative research. Comparative research is conducted by the Research Unit, a department within the Court's Registry. Lawyers from this department send requests to national lawyers working within the Registry commissioning a report on the way in which a particular legal matter is dealt with by their national legislation; this report, once confirmed by a national judge, should be submitted to the Research Unit. Therefore, the reports are prepared by the lawyers from their home countries who are familiar with the real social effect that particular norms have. Moreover, despite the diversity in Europe, comparativists in the European Court of Human Rights are still in a better position than those who compare laws globally because some legal systems worldwide are simply incompatible.

It is important to note that the comparative analysis conducted by the European Court of Human Rights is not aimed at explaining the differences or commonalities between different legal systems, which is often the case with academic comparative research. Kamba states that:

A systematic comparison which is the essence of comparative law, seeks to explain the similarities and divergences between the legal systems selected for comparison. The reasons for these differences and similarities are very often extra-legal and cannot be causally linked to any legal rule or principle. ${ }^{46}$

In the European Court of Human Rights, comparative analysis has a more descriptive and less analytical character. The Research Department provides a

\footnotetext{
${ }^{44}$ FF Stone, 'The End to be Served by Comparative Law' (1950) 25 Tulane Law Review 325, 332.

${ }^{45}$ Cruz (n 39) 236.

${ }^{46}$ Kamba (n 3) 230.
} 
description of the ways in which a particular legal matter is regulated in Member States and does not attempt to explain the differences and similarities. In Layla Sahin v. Turkey, the Court included the results of comparative law in the judgment without making any attempts to analyse the reasons behind them; the Court was more interested in the results themselves. ${ }^{47}$ For that reason, cultural determinacy can affect comparative law only if the legal practice is substantively different to the legal norms in place and is not documented by the national lawyer who prepares the report. In other cases, the Court is mainly concerned with the legal regulations of a particular legal matter.

\section{IV.II Legal Terms Translation}

An alternative challenge that the European Court of Human Rights faces in conducting comparative analysis concerns the translation of legal terms. This problem is linked to the one described above but is more technical and perhaps more relevant to the practice of the Court.

The same terms can describe different legal phenomena in different legal systems. Kamba notes that '[t]he term possession, for example, has a juridical meaning in French law different from that under English law' ${ }^{48}$ In some cases, the European Court of Human Rights is forced to compare similar legal concepts that do not match exactly. In J.A. Pye (Oxford) Ltd and J.A. Pye (Oxford) Land Ltd v. the United Kingdom, the Court stated that:

[i]t is plain from the comparative material submitted by the parties that a large number of member States possesses some form of mechanism for transferring title in accordance with principles similar to adverse possession in the common law systems, and that such transfer is effected without the payment of compensation to the original owner. ${ }^{49}$

\footnotetext{
${ }^{47}$ Leyla Sahin v. Turkey (App no 44774/98) [2004] ECHR 299, 55-65.

${ }^{48}$ Kamba (n 3) 222.

${ }^{49}$ J.A. Pye (Oxford) Ltd and J.A. Pye (Oxford) Land Ltd v. the United Kingdom (App no 44302/02) ]2005] Unpublished, 72.
} 
The Court was not in a position to compare procedures that were exactly the same as those in the case at hand; however, it seems to have compared legal procedures with different degrees of similarity. Reitz argues that this comparative analysis is in some sense comparing apples and oranges. ${ }^{50}$ However, it can be relevant as it may bring the Court closer to a conclusion on the appropriateness of a solution adopted by the State in question.

Some commentators have argued that "even in English speaking countries, homonyms may have different meanings. Hence, if the basic legal concepts are similar, different terms may be utilised so as to create an impression of divergence, and this may even occur within the same legal family. ${ }^{51}$ It is even more problematic if legal terms are compared with those from non-English-speaking countries. Kamba argues that ' $[\mathrm{a}] \mathrm{n}$ examination of the formal or textual legal norms, institutions and concepts in one system may not disclose corresponding categories in another system. This is particularly so where systems are rooted in completely different social types ${ }^{52}$ Again, this is partly rectified in the European Court of Human Rights' context, in that initial reports are submitted by the lawyers who speak the language of the Member State in question as their first language and English and/or French fluently. Moreover, the legal systems within the Council of Europe are not as diverse as legal systems internationally.

Reitz argues that good comparative analysis should describe the degree to which there are equivalents in the national systems of the Member States. ${ }^{53}$ The European Court of Human Rights has taken a number of important differences into account.. In the Shofman v. Russia ${ }^{54}$, for instance, the Court used comparative law to determine whether there was a commonly accepted standard in respect of time-limits for bringing proceedings contesting paternity. The Court came to the conclusion that there was no uniform standard. However, it was not enough to compare the periods of

\footnotetext{
${ }^{50}$ Reitz (n 4) 621.

${ }_{52}^{5}$ Kamba (n 3) 505 .

52 ibid 517.

${ }^{53}$ Reitz (n 4) 621.

${ }^{54}$ Shofman v. Russia 74826/01 [2005] Unpublished.
} 
time which different legal systems leave for this kind of legal action: it was also important to compare the point at which these terms begin.

[T] he difference between the various legal systems that is relevant to the present case is not only the length of the limitation period as such, but also its dies a quo. In some States the period is calculated from the moment the putative father knew or should have known that he had been registered as the child's father. The other States, which are approximately equal in number, accept as the starting point the date he learnt or should have learnt of circumstances casting doubt on the child's legitimacy. Many States in the latter category have introduced a second time-limit, making it possible to disclaim paternity only when the child is still young. A few States in which time starts to run from the child's birth, irrespective of the father's awareness of any other facts, also fall into the latter category. ${ }^{55}$

Therefore, the same numerical periods of time might lead to completely different outcomes for the claimant if it begins from the moment of a child's birth or from the moment of the father's awareness of the circumstances. This is an obvious example; sometimes these differences are hidden from researchers and can only be identified through examination of legal practice adopted in the particular state. Comparative analysis by the European Court of Human Rights seems to be more adequate and consistent when it considers norms in their context rather than purely as legal provisions enshrined in the legislation.

International courts face problems of translation on a regular basis. Judges approach the matters at issue from the perspective of their national legal and cultural backgrounds. Cruz argues that:

[b]y virtue of their legal background and origins, judges of the ECJ are bound to draw upon their own experience as lawyers within the member

\footnotetext{
${ }^{55}$ ibid 38.
} 
States. The Court seeks to evaluate and possibly utilise solutions provided by the legal systems from which the judges are drawn. ${ }^{56}$

The same principle is applicable to the judges of the European Court of Human Rights; they perceive different legal matters from the point of view of their national legal system and terminology.

The issue of term translation is common for all international tribunals dealing with different legal systems. It is relevant even where legal systems operate in the same language, with differing languages making term translation all the more complicated. For comparative research to be adequate, the European Court of Human Rights must take the context in which the norm is operating into account. Legal term translation is a matter which is engaged in every case; judges should be able to find a functionally equivalent term in their native languages and in English and/or French. This process can be called unavoidable or natural comparison.

\section{IV.III Law Cherry Picking}

Another important methodological challenge is that of a 'choice of laws'. The results of comparative research might be different if the researcher selects a slightly different list of states under consideration. ${ }^{57}$ McCrudden expresses his concerns of substantial cherry picking when selecting which legislation to quote. He argues that courts are more likely to quote foreign judgment or include comparative materials in cases where they support their own convictions. This can lead to arbitrariness and illegitimate judging. ${ }^{58}$

Örücü also voices concerns regarding consistency in the use of foreign law by national and international courts, arguing that:

\footnotetext{
${ }^{56}$ Cruz (n 39) 21.

${ }^{57}$ Kamba (n 3) 510; O Kahn-Freund, 'Comparative Law as an Academic Subject' (1966) 82 Law Quarterly Review.

${ }^{58}$ C McCrudden, 'A Common Law of Human Rights?: Transnational Judicial Conversations on Constitutional Rights' (2000) 4 Oxford Journal of Legal Studies 499, 507.
} 
the use of foreign cases is selective and there is no scientific approach to the choice. Neither is a specific methodology applied. In addition, the choice to use foreign judicial decisions remains largely in the realm of judicial discretion, and the exercise of this discretion may be related to many factors. ${ }^{59}$

The choice of laws is a very important part of the comparative research process because the European Court of Human Rights is not in a position to explore the legislation of all forty seven Member States. In this situation, the choice of law might affect the results of the research. Therefore, it is very important that the Court makes it clear in its judgment which laws were compared. In a number of cases the Court did not mention the countries or legislation under consideration. In K.U. v. Finland, the Court mentioned that '[a] comparative review of national legislation of the member States of the Council of Europe shows that in most countries there is a specific obligation on the part of telecommunications service providers to submit computer data.... ${ }^{60}$ The Court did not consider it necessary to list Member States and their particular legal provisions. It is certainly not possible to quote all relevant laws lest this overburden the judgment; however, comparative research should be transparent and accessible for the general public. Anything less than this leaves a judgment less convincing.

The judgment in question seems to be more justified if certain assumptions are proved correct by references to comparative research, with clear indications of the laws being examined. Lack of transparency leads to: the inability of parties to foresee the Court's findings; frustration amongst the general public and commentators, as established consensus can influence the law of the Member States, and; an inability to examine the judgments of the Court in terms of accuracy of the comparative research. The last point is crucial because comparative analysis might retain important persuasive authority in some cases.

\footnotetext{
${ }^{59}$ Örücü (n 5) 231.

${ }^{60}$ K.U.v. Finland (n 13) 32.
} 
The European Court of Human Rights should adopt certain recommendations regarding the number of laws to be examined in a particular case. Comparativists allow reasonable limitation of the volume of legislation under examination if it is done 'without defeating the purpose of the comparison. ${ }^{, 61}$ In every particular case, a lawyer in the Research Unit chooses the Member States whose legislation will then be considered. This choice should vary in accordance with the specific purpose of the research. The following recommendations might be seen as useful starting points for such research.

Firstly, the legislations of the States which belong to the same legal family as that in question should be examined, for instance, if the United Kingdom is a respondent State Irish law should be examined as well because both legal systems belong to common law. The rationale behind this proposal is derived from the idea that the most valuable and adequate comparison can be conducted between two or more legal systems with similar cultural and legal background ${ }^{62}$. '[I]n order to make meaningful comparisons, it is important to select systems that are at similar stage in their legal (and often their political, economic and social) evolution' ${ }^{63}$ Secondly, if the ECtHR has information that one of the Member States has recently changed its legislation in respect to the subject this law can be used to see the most up-to-date trends. Finally, the legislation of at least one Member State from each geographical regions of Europe should be examined; the ECtHR's section division might be useful in this respect, namely the law from at least one State from each of the sections should be under consideration. The main purpose of comparative research in a number of cases is find out whether there is European consensus in the area under consideration or not. The ECtHR can establish European consensus or European trend only in a situation if different European legal systems are considered. European consensus means lack of substantial disagreements in the area not only among the countries with similar legal systems but among the majority of the Member States. If the ECtHR

\footnotetext{
${ }^{61}$ HG Gutteridge, Comparative Law. An Introduction to the Comparative Method of Legal Study and Research (Second edn Wildy and Sons, Cambridge 1949), 74.

${ }^{62}$ Hoecke and Warrington (n 36) 509.

${ }^{63}$ Kamba (n 3) 520.
} 
follows these recommendations then the choice of law is going to be more consistent and representative.

\section{The Process of Comparison}

\section{V.I Collection of Comparative Data}

Selecting a method of comparative research is one of the great challenges in comparative law. ${ }^{64} \mathrm{~A}$ large body of literature has been written in an attempt to shed light on the issue of comparative methodology. Nevertheless, Zweigert and Kolz argue that there is "very little systematic writing about the method of comparative law. ${ }^{65}$ It may be beneficial to distinguish between comparative research conducted by academics and comparative research by lawyers on behalf of the European Court of Human Rights. The latter should be less advanced because academic comparison focuses on examining not only law itself, but also the reasons for the emergence of this law which are often irrelevant for Court's purposes. This simplified process should not affect the objectiveness of the findings and should serve practical purposes, providing the Court with information about possible solutions to the legal question at issue and leading to a conclusion regarding the presence or absence of European consensus if necessary. The research should not resolve fundamental legal problems (academic comparison may be designed to serve this aim), but rather should indicate whether there is a European trend in a particular area.

The process of comparison consists of a number of stages. There is no consensus in legal scholarship regarding the number of these stages or their content. An important procedural difference between academic comparative analysis and comparative research in the European Court of Human Rights is that, in the latter case, different stages of research are undertaken by different actors, namely, collection of

\footnotetext{
${ }^{64}$ Reitz (n 4); AT von Mehren, 'Choice-of-Law Theories and the Comparative-Law Problem' (1975) 23 The American Journal of Comparative Law 751; FC Auld, 'Methods of Comparative Jurisprudence' (1949) 8 The University of Toronto Law Journal 83.

${ }^{65} \mathrm{~K}$ Zweigert and H Kotz, Introduction to Comparative Law (Third edn Caledonian Press, Oxford 1998), 33.
} 
data is conducted by lawyers of the Court and analysis of this data is completed by judges.

Kamba suggests that there are three main stages of comparative research, namely the descriptive, identification and explanatory phases. ${ }^{66}$ At the first stage, the researcher explores and explains the legal provisions in a particular area of law. At the second stage, commonalities and differences between these legal provisions are identified. At the last stage, 'an attempt will be made to account for the resemblances and dissimilarities between systems, concepts or institutions'. ${ }^{67}$

Cruz outlined more detailed eight steps process of comparison. Firstly, identify the problem and state it as precisely as possible. Secondly, identify the foreign jurisdiction and, if possible, the parent legal family to which it belongs. Thirdly, decide which primary sources of law are going to be needed or which materials are available? Fourthly, gather and assemble the material relevant to the jurisdiction being examined. Fifthly, organise the material in accordance with headings reflecting the legal philosophy and ideology of the legal system being investigated. Sixthly, provisionally map out the possible answers to the problem, comparing carefully the different approaches, bearing in mind possible cultural differences or socio-economic factors, where relevant, and exploring any other non-legal factors. Seventhly, critically analyse the legal principles in terms of their intrinsic meaning. Lastly, set out your conclusions within a comparative framework with caveats and with critical commentary, wherever relevant, and relate it to the original purpose of your enquiry. ${ }^{68}$

The lawyers of the European Court of Human Rights involved in comparative analysis also go through these stages. However, the specific character of the Court as an international tribunal adds certain particular features to the comparative process conducted within the Court. They can be summarised as follows. Firstly, different stages are conducted by different lawyers. Secondly, materials and information is gathered by national lawyers and verified by the judges from the State at hand. Thirdly, there is a special unit within the Court that coordinate the comparative analysis. Fourthly, the judges are involved in comparative research only at two last

\footnotetext{
${ }^{66}$ Kamba (n 3) 511-512.

${ }^{67}$ Cruz (n 39) 240.

68 ibid 242-245.
} 
stages according to the Cruz's classification. Lastly, the ECtHR does not usually compare legal principles but solutions to particular legal problems, for example, regulation of adverse possession (J.A. Pye (Oxford) Ltd and J.A. Pye (Oxford) Land Ltd v. the United Kingdom), legal obligations of internet hosting providers (K.U. v. Finland), approaches to religious symbols in schools and universities (Leyla Sahin $v$. Turkey) and others.

At the European Court of Human Rights, there is a stage which precedes the first stage referred to by both Kamba and Cruz whereby the judge decides whether a particular case requires comparative law analysis. The Court is not in a position to conduct comparative research in all cases and moreover, this would not be necessary for a number of reasons, the most important of which is that, in most cases, the Court deals with legal issues that are similar to ones on which it has already adjudicated (clone cases). Judge Rapporteurs usually request comparative research in cases which involve complicated legal issues and where the issue falls in a legal area which is new for the Court or tests the limits of the its jurisdiction.

According to Cruz, the first stage of comparative analysis is problem identification. In the European Court of Human Rights, this stage is not always straightforward. In most cases the problem flows directly from the subject matter of the case itself. However, there are cases where the subject matter can be interpreted differently by different judges of the Court. In Leyla Sahin, the subject matter of the comparison formed the substance of a dissenting opinion. In that case the Court examined a Turkish ban on religious symbols in universities and tested its compliance with the Convention. The majority came to the conclusion that the State should be granted a wide margin of appreciation based on the diversity of practice within the Contracting Parties. ${ }^{69}$ Judge Tulkens (dissenting) stated:

I would perhaps have been able to follow the margin-of-appreciation approach had two factors not drastically reduced its relevance in the instant case. The first concerns the argument the majority use to justify the width of the margin, namely the diversity of practice between the

\footnotetext{
${ }^{69}$ Leyla Sahin v. Turkey (n 47) 109.
} 
States on the issue of regulating the wearing of religious symbols in educational institutions and, thus, the lack of a European consensus in this sphere. The comparative-law materials do not allow of such a conclusion, as in none of the member States has the ban on wearing religious symbols extended to university education, which is intended for young adults, who are less amenable to pressure. $^{70}$

Concurring with this dissenting opinion, some commentators argue that the subject of comparison was chosen arbitrarily. ${ }^{71}$ In order to make comparative data relevant to the matter at hand, the subject of the comparative analysis should be carefully and precisely articulated.

Steps two to five are conducted by the lawyers of the Court under the supervision of national judges and lawyers of the Research Unit in the Registry. The most important issue during these steps is to provide the Chamber or Grand Chamber with consistent and reliable comparative data which can be assessed by the judges during the preparation of their judgment. It is important to specify the list of the states whose law will be examined, and functionally equivalent terms and legal concepts should be analysed. The challenges associated with this exercise were outlined in the previous section. Data collected and systemised during steps two to five will be assessed and analysed at steps seven and eight.

As one may notice from the classifications expounded by Cruz, academic comparative research does not end with identification of differences or similarities regarding treatment of a particular legal issue. The same idea was advocated by Kamba: 'the systematic comparison entails...also the explanation of such divergences and resemblances'. ${ }^{72}$ Comparison within the European Court of Human Rights' jurisdiction serves two purposes, namely informative and persuasive. If the Court views the comparative data simply as a source of inspiration and information, judges

\footnotetext{
${ }^{70}$ ibid. Dissenting opinion of Judge Tulkens.

${ }^{71}$ N Gibson, 'Faith in the Courts: Religious Dress and Human Rights' (2007) 66 Cambridge Law Journal 657, 680 .

${ }^{72}$ Kamba (n 3) 511.
} 
go no further in their analysis. If the Court is aiming to establish the presence or absence of European consensus, analysis of comparative data is an important stage.

The same comparative data can lead different judges to mutually exclusive conclusions. ${ }^{73}$ In the case Odievre v. France ${ }^{74}$ the European Court of Human Rights assessed compliance with the European Convention of a provision in French law that gives a woman the right to give birth anonymously and to ensure that the child will not be entitled to any information about his or her mother. The Court analysed the legislation of Contracting Parties on this matter and concluded that:

...most of the Contracting States do not have legislation that is comparable to that applicable in France, at least as regards the child's permanent inability to establish parental ties with the natural mother if she continues to keep her identity secret from the child she has brought into the world. However, it notes that some countries do not impose a duty on natural parents to declare their identities on the birth of their children and that there have been cases of child abandonment in various other countries that have given rise to renewed debate about the right to give birth anonymously. In the light not only of the diversity of practice to be found among the legal systems and traditions but also of the fact that various means are being resorted to for abandoning children, the Court concludes that States must be afforded a margin of appreciation to decide which measures are apt to ensure that the rights guaranteed by the Convention are secured to everyone within their jurisdiction. ${ }^{75}$

This argument was challenged by the dissenting Judges Wildhaber, Sir Nicolas Bratza, Bonello, Loucaides, Cabral Barreto, Tulkens and Pellonpää. They argued that the majority was in a position to pronounce on the lack of European consensus but that they failed to consider 'various international instruments that play a decisive role in achieving a consensus and which seek to ensure a balance between competing rights in

\footnotetext{
${ }^{73}$ Mahoney (n 19) 148.

| ${ }_{75}^{74}$ Odièvre v. France 42326/98 ECHR 2003-III.

75 ibid 47.
}

Formatted: Portuguese Brazil 
individual cases ${ }^{76}$ In Marckx v. Belgium,${ }^{77}$ the Court based its decision regarding the presence or absence of European consensus on the relevant international treaty on whether in the Court had been reluctant to do so in the Odievre case. The European Court of Human Rights seems to lack consistency with regard to the type of consensus it is ready to find: it can be identified through the analysis of municipal legislation ${ }^{78}$, international treaties ratified by all or some of the Contracting Parties ${ }^{79}$ or some sort of combination of these two sources with more emphasis on either municipal or international legislation. ${ }^{80}$ Within this framework, the judgments of the Court seem inconsistent and unpredictable; at times it has been satisfied with consensus on an international level (D.H v. Czech Republic ${ }^{81}$ ) while at others, it has held that international law is not concrete enough (Chapman v. the United Kingdom ${ }^{82}$ ). It is hard to measure the 'concreteness' of consensus and the Court was not in a position to provide even an approximate scale for this measurement. The Court is expected to explain when an international treaty is sufficient to constitute European consensus, whether this treaty should be binding or not and whether it should be implemented into domestic legislation.

\section{V.II Assessment of Comparative Data}

If the European Court of Human Rights identifies a consensus, it does not follow that a particular solution must be adopted automatically. In certain

\footnotetext{
${ }^{76}$ ibid. Dissenting opinion. 15.

${ }^{77}$ Marckx v. Belgium (App no 6833/74) (1979) A31 p.3. In Marckx the European Court of Human Rights dealt with the issue of unequal legal position of the children born outside and inside the wedlock. The Court used the Brussels Convention of 12 September 1962 on the Establishment of Maternal Affiliation of Natural Children, which was prepared by the International Commission on Civil Status and entered into force on 23 April 1964 and the European Convention of 15 October 1975 on the Legal Status of Children Born out of Wedlock, as signs of common ground in the law of the Contracting States.

${ }^{78}$ Leyla Sahin v. Turkey (n 47); Unal Tekeli v. Turkey (n 20); Vo v. France (App no 53924/00) (2005) 1 Inquest LR; Pretty v. the United Kingdom and others (App no 2346/02) (2002) Unpublished.

${ }_{79}$ Marckx v. Belgium (n 77), Chapman v. the United Kingdom (App no 27238/95) 30 January 2001

Times Law Reports, D.H. and others v. the Czech Republic and others (App no 57325/00) (2007) Unpublished.

${ }^{80}$ Christine Goodwin v. the United Kingdom (App no 28957/95) 12 July 2992 Times Law Reports; K.U.

v. Finland and others (n 13).

${ }^{81}$ D.H. and others v. the Czech Republic (n 79).

${ }^{82}$ Chapman v. the United Kingdom (n 79).
} 
circumstances, the minority position does not indicate that a Convention right has been violated by the Member State.

Comparative research can lead the European Court of Human Rights to three possible conclusions. First, the Court is in a position to claim that European consensus exists in the area and the law in question constitutes a part of this. In Stoll v. Switzerland $^{83}$ the applicant argued that the State had breached its Convention obligation under Article 10 by imposing a criminal sanction for disclosure of confidential information. The Court noted that 'a consensus appears to exist among the Member States of the Council of Europe on the need for appropriate criminal sanctions to prevent the disclosure of certain confidential items of information, ${ }^{84}$ However, a situation in which the Court upholds that the legislation at issue constitutes part of European consensus is quite rare. One might find few cases where the Court reached this conclusion. Moreover, even if the Court admits that the law is within European consensus, it does not halt its analysis at this point, it continues to consider the more particular issues of the case, for instance, whether the particular measures are proportionate to the pursued aim. In the above mentioned case of Stoll v. Switzerland, for example, the Court, after stating that the Swiss law was similar to the laws in the majority of European States, also considered whether the fine for the disclosure of information was proportionate or not. The reason for that is, arguably, linked to the purpose of the European consensus argument. The judges of the European Court of Human Rights, when interviewed, confirmed that they mostly require consensus and comparative analysis in situations where they are on the 'new ground ${ }^{85}$ New grounds are understood to be legal matters that can arguably be governed by the European Convention but comprise issues on which the Court has not yet ruled.

The position of municipal law as a part of European consensus does not guarantee that the European Court of Human Rights will find no violation of the Convention. In B. and L. v. the United Kingdom, the complaint concerned the inability of a former father-in-law to marry his former daughter-in-law according to British law.

\footnotetext{
${ }^{83}$ Stoll v. Switzerland (App no 69698/01) (2006) Unpublished.

${ }^{84}$ ibid 155.

${ }^{85}$ K Dzehtsiarou, Unpublished interview with Judge Myjer (European Court of Human Rights, Strasbourg 2009).
} 
The Court concluded that a prohibition similar to the British one could be found in the laws of a large number of the Contracting Parties ${ }^{86}$. Nevertheless the Court further stated that:

The Court must however examine the facts of the case in the context pertaining in the United Kingdom. It observes that this bar on marriage is aimed at protecting the integrity of the family (preventing sexual rivalry between parents and children) and preventing harm to children who may be affected by the changing relationships of the adults around them. These are, without doubt, legitimate aims. [However, u]nder United Kingdom law the bar on a marriage of this degree of affinity is not subject to an absolute prohibition. Marriages can take place, pursuant to a personal Act of Parliament. From the information before the Court, it transpires that individuals in a similar situation to these applicants have been permitted to marry..., where there were also children in the household, it was declared that the impediment placed on the marriage served no useful purpose of public policy. The inconsistency between the stated aims of the incapacity and the waiver applied in some cases undermines the rationality and logic of the measure. $^{87}$

The European Court of Human Rights held that Article 12 of the Convention had been violated in this case. While the Court is not obliged to follow European consensus, 'the circumstances would have to be highly exceptional for the European Court to declare a common practice or legislative policy of the Contracting States to be contrary to the Convention'. ${ }^{88}$ In B. and L. v. the UK the Court did not deem the law in question to be a violation of the Convention but it is submitted that the circumstances of the case make it impossible for the Court to follow common practice.

\footnotetext{
${ }_{87}^{86}$ B. and L. v. the United Kingdom (App no 36536/02) (2004) Unreported 36.

${ }^{87}$ ibid.

${ }^{88}$ P Mahoney, 'Judicial Activism and Judicial Self-Restraint in the European Court of Human Rights:

Two Sides of the Same Coin' (1990) 11 Human Rights Law Journal 57, 75.
} 
In certain cases the European Court of Human Rights did not find breaches of the Convention because the State in question was not the only one of its kind which implemented the infringing legal provisions. In Georgian Labour Party v. Georgia, ${ }^{89}$ the Court dealt with the compliance of the Georgian system of the voters' registration with the European Convention. The Court stated that:

...it must be noted that the respondent State was not alone in opting for such a system of voter registration: several Western European democracies, in particular the United Kingdom and Portugal, also rely to a considerable extent on voters' individual declarations when compiling the national electoral rolls; Portuguese law even envisages individual criminal responsibility for those who evade taking the necessary steps for electoral registration. Thus, there can be a diversity of possible choices in the system of voter registration amongst the Contracting States. None of these criteria should, however, be considered more valid than any other, provided that the expression of the will of the people through free, fair and regular elections is guaranteed. ${ }^{90}$

In finding that the legislation is not unique among Contracting Parties, the European Court of Human Rights acknowledges that there is no consensus and no uniform approach in the particular area. In the recent case of Egeland and Hanseid v. Norway, ${ }^{91}$ the Court also used the above formula:

It is to be noted that Norway is not in an isolated position with regard to prohibition to photograph charged or convicted persons in connection with court proceedings. According to information available to the Court, similar prohibitions exist in the domestic laws of Cyprus, England and Wales, and legal restrictions apply also in Austria and

\footnotetext{
${ }^{89}$ Georgian Labour Party v. Georgia (App no 9103/04) (2008) Unpublished.

${ }^{90}$ ibid 91.

${ }^{91}$ Egeland and Hanseid v. Norway (App no 34438/04) (2009) Unpublished.
} 
Denmark. Whilst in a number of countries such matters are left to selfregulation by the press, it cannot be said that there is a European consensus to this effect. ${ }^{92}$

Here the Court referred to 'European consensus up-side-down', stating that it can identify a violation if the law in question cannot be found in any other legal system in Europe. Therefore, the Court allows a wide margin of appreciation unless only one country remains outside the common trend.

Secondly, the European Court of Human Rights can reach the conclusion that there is no European consensus regarding the issue in question. In this situation the Court normally confirms that the issue falls within the state's margin of appreciation. In Evans v. the United Kingdom the Court stated '[w]here... there is no consensus within the Member States of the Council of Europe, either as to the relative importance of the interest at stake or as to the best means of protecting it, particularly where the case raises sensitive moral or ethical issues, the margin will be wider' ${ }^{93} \mathrm{~A}$ wide margin of appreciation means that the Court will not find the law or practice of the Member State to be in breach of the Convention if this matter falls under the discretion of the Member State and that the Court would generally respect the legislature's policy choice unless it is manifestly without reasonable foundation'. ${ }^{94}$

The European Court of Human Rights did not provide a definition of what it considers to be an intervention which is 'manifestly without reasonable foundation.' In TV Vest As \& Rogaland Pensjonistpartiv. Norway, the Court dealt with a prohibition on television broadcasting of political advertising laid down in the Broadcasting Act enacted in Norway. The Court confirmed that there was no European consensus in the area and that quite a wide margin of appreciation is granted to Member States. ${ }^{95}$ However, the Court took into account the special circumstances of this case and found a breach of Article 10 of the Convention. The Court noted that the legislation in question was aimed to remove disadvantages between political parties that have

\footnotetext{
92 ibid 54.

${ }^{93}$ Evans v. the United Kingdom (App no 6339/05) 2 May 2007 Times Law Reports 77.

${ }^{94}$ Dickson v. the United Kingdom (App no 44362/04) 21 December 207 Times Law Reports 78.

${ }^{95}$ TV Vest AS and Rogaland Pensjonistparti v. Norway (App no 21132/05) (2008) Unpublished 65-66.
} 
different financial resources, namely, that the parties with small budgets would otherwise be underrepresented on television. However, the Court continued that the law in question failed to achieve this aim. In contrast to the major political parties, which were given a large amount of attention in the edited television coverage, the small parties were hardly mentioned. Therefore, paid advertising on television became the only way for these parties to get their message across to the public through that type of media. ${ }^{96}$

In Hirst v. the United Kingdom, the European Court of Human Rights dealt with a legal provision according to which convicted prisoners would be deprived the right to vote. The Court conducted comparative analysis in this case and while it agreed that there was no European consensus, stated that this lack of consensus cannot be decisive in this case. ${ }^{97}$ The Court held that:

while the Court reiterates that the margin of appreciation is wide, it is not all-embracing. The [relevant] provision imposes a blanket restriction on all convicted prisoners in prison. It applies automatically to such prisoners, irrespective of the length of their sentence and irrespective of the nature or gravity of their offence and their individual circumstances. Such a general, automatic and indiscriminate restriction on a vitally important Convention right must be seen as falling outside any acceptable margin of appreciation, however wide that margin might be, and as being incompatible with Article 3 of Protocol No. $1 .^{98}$

These two cases can be compared with the case Appleby and Others v. the United Kingdom, which concerned an alleged violation of Article 10 of the Convention. The applicants began collecting signatures for a petition to persuade the council to reject a project to rebuild the public playing field. They tried to set up a stall and canvass views in 'The Galleries', a shopping mall in Washington that had become the effective town centre. They were prevented from doing so, however, by Postel, a

\footnotetext{
${ }^{96}$ ibid 70-75.

${ }^{97}$ Hirst v. the United Kingdom (App no 40787/98) 03 August 2001 Times Law Reports 81.

98 ibid 82.
} 
private company which had bought most of the shopping area and had, under domestic law, the power to exclude anyone conducting unauthorised activities on its land. ${ }^{99}$ The applicants brought their claim that the State did not fulfill its positive obligation under article 10 of the Convention to the European Court of Human Rights. The Court failed to find any uniformity in legal regulation of this matter in Europe and stated that '[i]t cannot be said that there is as yet any emerging consensus that could assist the Court in its examination in this case concerning Article 10 of the Convention'. ${ }^{100}$ The same court had come to the opposite conclusion to that which it had delivered in the TV Vest As \& Rogaland Pensjonistparti case. The Court held in this case that the State did not breach article 10 .

Lack of consensus does not automatically leave the issue within the area of the state's discretion. The European Court of Human Rights can further examine the law to determine whether it is manifestly unreasonable and appropriate to leave the matter to the state's discretion. European consensus or lack of it establishes a rebuttable presumption which can be overcome with convincing reasons brought by other means of interpretation.

A third situation emerges where the State's legislation opposes European consensus. In the above mentioned case Unal Tekeli v. Turkey, Turkey appeared to be the last state in Europe where it was illegal for a woman to remain with her maiden surname after she married. ${ }^{101}$ The Court held that this law violated Article 14 when taken in conjunction with Article 8 of the Convention. However, this is not the only possible outcome for the State if it finds itself outside European legal trend. The following outcomes might occur. Firslty, the Member State's law falls outside European consensus and there is no reasonable justification for that as in the mentioned above Unal Tekeli v. Turkey case. Secondly, the Member State has a particularly strong justification for having the law in question even if this law is different to common European trend. Lastly, the law in question can be outside

\footnotetext{
${ }^{99}$ Appleby and Others $v$. the United Kingdom (App no 44306/98) 13 May 2003 Times Law Reports 1021. 
European consensus if it provides even further protection of human rights than in the majority of the Member States.

In the first option the consequences are quite clear: the Court normally holds a violation of the Convention right. In the second situation the result is not so obvious. The state may try to justify its position with social, economic and cultural reasons. Brems argues that European consensus establishes a rebuttable presumption that should be followed unless there is moral justification to the contrary. ${ }^{102}$ In the above mentioned case of Leyle Sahin v. Turkey, the European Court of Human Rights assessed the compliance of the Turkish legal prohibition on wearing the Islamic headscarf in universities to the Convention. The Court conducted comparative research and noted that certain European countries had placed a ban on wearing religious signs at school. However, only Azerbaijan, Turkey and Albania had introduced regulations on wearing the Islamic headscarf in universities. ${ }^{103}$ Nevertheless the Court argued that there is no uniform approach towards regulation of this issue in educational establishments. The Court pointed out that there is 'diversity of the approaches taken by national authorities on the issue'. ${ }^{104}$

It seems that the European Court of Human Rights chose to distinguish legal regulations on wearing religious signs at school from wearing such signs in university. University students need much less paternalistic treatment by the state than pupils at school. This point was emphasised by Judge Tulkens in her dissenting opinion. She stated that ' $[\mathrm{t}]$ he comparative-law materials do not allow of such a conclusion [of lack of European consensus], as in none of the member States has the ban on wearing religious symbols extended to university education, which is intended for young adults, who are less amenable to pressure'. ${ }^{105}$

In this case it seems appropriate to take the special cultural and social circumstances of Turkey into account rather than attempt to find consensus in respect to the issue. Some commentators argue that the case must be read in the specific political, cultural, and religious context.

${ }^{102}$ E Brems, Human Rights: Universality and Diversity (Martinus Nijhoff Publishers, Hague 2001), 420.

${ }^{103}$ Leyla Sahin v. Turkey (n 47) 55-65.

104 ibid 109.

${ }^{105}$ ibid. Dissenting opinion. Judge Tulkens. 
It might be contended that it is the international nature of the Sahin judgment that explains it... The especial political sensitivity of Turkey's situation, on the borders of Syria, Iraq and Iran and facing the real threat from within of extreme Islamist political parties gaining power and seeking 'to impose on society as a whole their religious symbols and conception of a society founded on religious precepts' may help explain the judgment. ${ }^{106}$

Therefore, the situation in Turkey is quite unique and can hardly be compared with the majority of other European States. For that particular reason the European consensus argument seems less relevant and can be rebutted by the specific political, cultural, and social context of Turkey.

Gibson argues that '[t]he Court in Sahin focuses on the 'issue' of religious dress in an educational context; arguably, however, its primary concern is the broader "issue" of religion's relationship with the state and, specifically, Turkish secularism, ${ }^{107}$ The Commission adopted this line of reasoning in the case Karaduman v. Turkey. ${ }^{108}$

In Karaduman, the University of Ankara did not issue a certificate proving that the applicant obtained a Bachelor's Degree because she was wearing a religious headscarf on the photograph she provided. This photograph did not comply with university regulations. In assessing the merits of the case the Commission pointed out that:

Especially in countries where the great majority of the population owe allegiance to one particular religion, manifestation of the observances and symbols of that religion, without restriction as to place and manner,

\footnotetext{
${ }^{106}$ T Lewis, 'What Not to Wear: Religious Rights, the European Court, and the Margin of Appreciation' (2007) 56 International and Comparative Law Quarterly 395, 412.

${ }^{107}$ Gibson (n 71) 680.

${ }^{108}$ Karaduman v. Turkey (1993) DR 7493.
} 
may constitute pressure on students who do not practise that religion or those who adhere to another religion. ${ }^{109}$

This argument seems like a clear reference to cultural justification of the restrictions in question and supports the European Court of Human Rights' departure from the European consensus doctrine. Such reasons should be real and convincing in order to rebut the presumption established by European consensus.

Thirdly, new legislation may constitute a new step forward in human rights development. The evolution of laws in European states is an everyday process. New laws can appear to be in a minority position immediately after adoption, only to later become part of a pan-European trend. If the transsexuals' rights cases ${ }^{110}$ came before the Court sixty years ago, it could easily find European consensus in non-recognition of the rights of transsexuals.

If the European Court of Human Rights uses the consensus doctrine without preceding analysis, it may become a tool for stagnation and preservation of the status quo. The problem lies in recognising this new trend. Brems supposes that the Court may refer to other international texts. ${ }^{111}$ Indeed, it may be useful for the identification of a trend in international human rights law. The Court may take into account the findings of different institutions in examining a certain area of law and the opinions of well-known lawyers and human rights defenders. It is noteworthy that the Court often builds its judgments on international treaties and accepts amicus curiae by human rights non-governmental organisations.

\section{CONCLUSION}

Comparative law serves a very practical purpose in the European Court of Human Rights' case law. It is no longer an amusing academic puzzle which lacks any useful application. However, this practical purpose is not universal and comparative

\footnotetext{
109 ibid.

110 Sheffield and Horsham v. the United Kingdom (1998) 27 EHRR 163; Christine Goodwin v. the United Kingdom (n 80); B. v. France and others (57/1990/248/319).

${ }^{111}$ Brems (n 102).
} 
law serves two specific functions. The Court employs comparative law for an informative purpose if it is designed to map a spectrum of particular solutions to legal matters in question. Otherwise, comparative law analysis serves as persuasive authority for the findings of the Court.

In so doing, a broader question arises as to whether the European Court of Human Rights should use comparative law in its decision-making at all. The Court is charged with supervising the compliance of Contracting Parties with the Convention and the comparative data comes directly from the States under its supervision. However, the way in which the Convention is phrased occasionally gives the Court space for more than mere interpretation, an opportunity more comparable to lawmaking, which cannot be exercised in a vacuum if it is to be legitimate. The Court needs ground on which to base its findings and an instrument to check the appropriateness of its interference. Moreover, the way in which the Court uses comparative analysis must not pose a threat to human rights protection provided by the Convention, since the existence of European consensus, or lack thereof, do not establish an absolute presumption of acceptance of the particular rule. It can readily be rebutted by alternative means of reasoning.

The European Court of Human Rights faces important challenges in conducting its comparative analysis. Legal terms translation, adequacy, cultural and contextual propriety of comparison and law cherry picking are among the most crucial, applicable to both academic comparison and comparative analysis undertaken by the Court. The Court, however, arguably finds itself in a better position than academics due to its international character and the plethora of lawyers from all forty seven Member States at its disposal. Moreover, recent developments, namely the establishment of the Research Unit which is well equipped to produce reliable and objective comparative studies, eliminate some of the problems that academics have to endure.

The comparative analysis of the European Court of Human Rights goes through a number of stages. They can be divided in two major groups: collecting of and assessing the data. These two stages of research are conducted by different organs and at different stages of proceedings. The collection of the data is conducted by 
national lawyers and accumulated in the Research Unit; its assessment is completed by judges.

Judges of the Court might come to the conclusion that consensus on the matter at issue exists or is lacking. In the former case the presumption is that the law which contradicts the European consensus should be held as a breach of same and, in the latter case, the Court leaves the issue to the state's discretion. However, these presumptions can be rebutted. If the Court is in a position to find consensus, it may not follow it if the state has particularly persuasive reasons to maintain its particular legislation. In the circumstances where there is a lack of consensus, the European Court of Human Rights can still deem the law in question to be a violation of the Convention if it is manifestly unreasonable. 